\title{
EFISIENSI PEMANFAATAN MEDIA E LEARNING DI MASA PANDEMI COVID - 19 PADA PENDIDIKAN AGAMA KRISTEN DI SMA NEGERI 2 TANJUNG SELOR
}

\author{
ROSLINA PANJAITAN \\ SMA Negeri 2 Tanjung Selor \\ e-mail: barnabas.lina@gmail.co.id
}

\begin{abstract}
ABSTRAK
Penelitian ini bertujuan untuk mendeskripsikan perlunya E-Learning dimanfaatkan di tengah Pandemi, dan mengidentifikasikan Efisiensi Pemanfaatan E-Learning dalam pembelajaran daring. Penelitian ini mengunakan metode study pustaka dengan pendekatan deskriptip. Hasil penelitian menggunakan dokumentasi keaktipan peserta didik melalui absensi dan respon berupa pengumpulan tugas-tugas peserta didik, Absensi dan Cheklist variabel kegiatan. Subyek penelitian Siswa Kristen kelas X dengan jumlah 45 orang. Kesimpulan dari penelitian ini adalah keaktifan peserta didik meningkat mulai pembelajaran KD 1 sampai KD 4, sebesar 90 $\%$ yaitu 40 peserta didik aktif dalam mengikuti pembelajaran dan pengumpulan tugas-tugas dan $10 \%$ yaitu 5 peserta didik yang kurang aktif mengikuti.
\end{abstract}

Kata Kunci : E-Learning, Keaktifan peserta didik, COVID-19

\section{PENDAHULUAN}

Dunia saat ini sedang dilanda coronavirus. Coronavirus itu sendiri adalah virus yang menyebabkan penyakit mulai dari gejala ringan sampai berat. Ada setidaknya dua jenis corona virus yang diketahui yang menyebabkan penyakit yang dapat menimbulkan gejala berat. Tanda dan gelaja umum infeksi COVID-19 antara lain gejala gangguan pernapasan akut seperti demam, batuk, dan sesak napas. Masa inkubasi rata-rata 5- 6 hari dengan masa inkubasi terpanjang 14 hari. Pada tanggal 30 Januari 2020 WHO telah menetapkan sebagai kedaruratan kesehatan masyarakat yang meresahkan dunia. Pada tanggal 2 Maret 2020, Indonesia melaporkan kasus konfirmasi COVID-19 sebanyak 2 kasus. Sampai dengan tanggal 16 Maret 2020 ada 10 orang yang dinyatakan positif corona. (Yurianto, Ahmad, Bambang Wibowo, 2020).

Dampak virus COVID-19 terjadi diberbagai bidang seperti sosial, ekonomi, pariwisata dan pendidikan. Surat Edaran (SE) yang dikeluarkan pemerintah pada 18 Maret 2020 segala kegiatan didalam dan diluar ruangan di semua sektor sementara waktu ditunda demi mengurangi penyebaran virus corona terutama pada bidang pendidikan. Pada tanggal 24 maret 2020 Menteri Pendidikan dan Kebudayaan Republik Indonesia mengeluarkan Surat Edaran Nomor 4 Tahun 2020 Tentang Pelaksanaan Kebijakan Pendidikan Dalam Masa Darurat Penyebaran COVID. 19.

Dunia pendidikan menuntut untuk tetap dapat menyelenggarakan pendidikan bagi peserta didik walau dengan Pembelajaran Jarak Jauh, sebagaimana tercantum dalam Surat Edaran Mendikbud Nomor 4 Tahun 2020 Tentang Pelaksanaan Kebijakan Pendidikan dalam Masa Darurat Penyebaran Covid-19 bahwa proses Belajar dari Rumah (BDR) melalui Pembelajaran Daring/ Jarak Jauh (PJJ) dilaksanakan untuk memberikan pengalaman belajar yang bermakna bagi siswa, tanpa terbebani tuntutan menuntaskan seluruh capaian kurikulum untuk kenaikan kelas maupun kelulusan.

Pendidikan merupakan suatu faktor penting dalam kemajuan suatu bangsa dengan mempersiapkan bekal yang cukup bagi sumber daya manusia agar menjadi manusia berkualitas dan bermanfaat (Widodo, 2015). Terdapat tiga jalur pendidikan untuk mempersiapkan manusia berkualitas di Indonesia sebagaimana termaktub dalam Undang-undang Sisdiknas No. 20 tahun 2003 pasal 13 ayat 1 yaitu mengenai jalur pendidikan formal, pendidikan nonformal dan pendidikan informal. Pendidikan dijadikan sebagai suatu dasar yang berperan dalam mengembangkan diri tiap individu (Nurhaida \& Musa, 2015). 
Maka yang dimaksud dengan e-learning dalam artikel ini adalah pembelajaran yang dilakukan tidak secara tatap muka tetapi pembelajaran jarak jauh dengan bantuan perangkat eloktronik atau gadget seperti deskptop, laptop, atau smart phone yang dimiliki oleh guru dan siswa/orang tua siswa sehingga proses pembelajaran tetap berlangsung dalam situasi pandemi Covid-19

Surat Edaran atau kebijakan yang dikeluarkan oleh baik Menteri Dalam Negeri, Menteri Pendidikan dan Kebudayaan, maupun Menteri Agama tentunya bertujuan untuk keselamatan orang banyak agar tidak terpapar viruscorona. Di sisi lain jika peserta didik terlalu lama tidak mengalami pembelajaran dengan guru, tidak ada komunikasi dan interaksi sosial dengan sesama murid, dikuatirkan dampak psikologis (kejenuhan di rumah, timbul rasa malas belajar, niat negatif) bagi peserta didik.

Di tengah Pandemi Covid 19 yang didukung dengan Kebijakan Pemerintah membatasi kegiatan melalui Protokol Kesehatan 5M: Memakai Masker, Mencuci Tangan, Menjaga Jarak, Menghindari Kerumunan, Mengurangi Aktivitas di luar, maka semua kegiatan pembelajaran diarahkan untuk Belajar Jarak Jauh (Belajar Dari Rumah) dengan menggunakan media teknologi informasi dan komunikasi seperti Laptop Hand Phone mulai dari vitur yang paling sederhana yaitu WhatsApp, Videocall, sampai dengan vitur Google meet, ruang guru (elearning).

Media teknologi informasi dan komunikasi (Laptop, HP) yang didukung dengan tersedianya jaringan internet tentunya menjadi solusi untuk pelaksanaan pembelajaran jarak jauh. Permasalahan yang muncul apakah media E-Learning perlu dimanfaatkan sebagai satusatunya solusi, sementara tidak semua/tidak 100 persen siswa memiliki Laptop atau HP? Efisienkah pemanfaatan media E-Learning dalam pembelajaran sementara tidak 100 persen di rumah siswa terjangkau jaringan internet.

Dari uraian terkait Pandemi Covid 19 di mana menghimpunkan orang banyak / kerumunan dilarang dan proses pembelajaran tetap dilaksanakan dengan memanfaatkan Media Elektronik Learning (E-Learning), maka rumusan masalah dalam penelitian ini adalah : (1) Mengapa E-Learning perlu dimanfaatkan di tengah Pandemi Covid 19 ini? (2) Bagaimana Efisiensi Pemanfaatan E-Learning dalam Pembelajaran (Pendidikan Agama Kristen)? Maka tujuan dari penelitian ini yaitu: Pertama mendeskripsikan perlunya E-Learning dimanfaatkan di tengah Pandemi. dan yang kedua: Mengidentifikasikan Efisiensi Pemanfaatan E-Learning dalam pembelajaran.

\section{METODE PENELITIAN}

Penelitian ini merupakan penelitian kualitatif dengan pendekatan deskriptip. Penelitian ini dilakukan dengan metode pengkajian literatur, observasi di lapangan yaitu SMA Negeri 2 Tanjung Selor. Data yang diperoleh merupakan data hasil evaluasi dari siswa kelas X SMA Negeri 2 Tanjung Selor selama proses pembelajaran menggunakan media E-Learning Learning dengan menggunakan aplikasi Videoscribe. Penelitian ini menggunakan pendekatan kualitatif dengan métode Studi Pustaka. Karena sumber data maupun hasil dari penelitian kepustakaan (library research) berupa deskripsi atau penjelasan.

Langkah yang dilakukan dalam Studi Pustaka ini adalah: Pertama, mengumpulkan bahan-bahan penelitian, karena dalam penelitian ini adalah penelitian kepustakaan, maka bahan yang dikumpulkan adalah berupa informasi atau data empirik yang bersumber dari buku-buku, jurnal, hasil laporan penelitian resmi maupun ilmiah dan literatur lain yang mendukung tema penelitian ini; Kedua, membaca bahan kepustakaan, dan menggali secara mendalam bahan bacaan yang memungkinkan akan menemukan konsep atau gagasan dan penjelasan yang terkait dengan judul penelitian; Ketiga, Membuat catatan penelitian; Keempat, Mengolah catatan penelitian. Semua bahan yang telah dibaca kemudian diolah atau dianalisis untuk mendapatkan suatu kesimpulan yang disusun dalam bentuk laporan penelitian . 


\section{HASIL DAN PEMBAHASAN}

\section{A. Hasil Penelitian}

Berdasarkan hasil kajian pustaka dari berbagai referensi dan artikel penelitian terdahulu berkaitan dengan efisiensi penggunaan E-Learning pada pembelajaran daring/jarak jauh di masa pandemi covid-19, berikut temuan dalam kajian tersebut disajikan dan direfleksikan atas studi pustaka yang dilakukan. Hasil penelitian disajikan pada tabel 1 di bawah ini.

Tabel 1. Hasil Penelitian terkait Studi Pustaka

\begin{tabular}{|c|c|c|c|}
\hline No & Artikel Penelitian & Temuan & Refleksi \\
\hline 1 & $\begin{array}{l}\text { Penggunaan E- } \\
\text { Learning Madrasah di } \\
\text { Tengah Pandemi } \\
\text { Covid 19 } \\
\text { (Nopriati, 2020) }\end{array}$ & $\begin{array}{l}\text { Belajar menggunakan e-Learning } \\
\text { memilki manfaat diantaranya: } 1 . \\
\text { Fleksibel. e-Learning memberi } \\
\text { fleksibilitas dalam memilih waktu } \\
\text { dan tempat untuk mengakses } \\
\text { perjalanan. 2. Belajar Mandiri. } e \text { - } \\
\text { Learning memberi kesempatan bagi } \\
\text { pembelajar secara mandiri } \\
\text { memegang kendali atas keberhasilan } \\
\text { belajar. 3. Efisiensi Biaya. } e \text { - } \\
\text { Learning g memberi efisiensi biaya } \\
\text { bagi administrasi penyelenggara, } \\
\text { efisiensi penyediaan sarana dan } \\
\text { fasilitas fisik untuk belajar dan } \\
\text { efisiensi biaya bagi pembelajar } \\
\text { adalah biaya transportasi dan } \\
\text { akomodasi. }\end{array}$ & $\begin{array}{l}\text { Pembelajaran } \\
\text { menggunakan e- } \\
\text { learning membantu } \\
\text { siswa mandiri dalam } \\
\text { belajar dan efisiensi } \\
\text { dari segi administrasi } \\
\text { penyelenggaraan, } \\
\text { efisiensi dari } \\
\text { pembiayaan } \\
\text { transportasi siswa. }\end{array}$ \\
\hline 2 & $\begin{array}{l}\text { Efektivitas } \\
\text { Pembelajaran Daring } \\
\text { Di masa Pandemi } \\
\text { Covid } 19 \text { (Sri Harmani, } \\
\text { 2020) }\end{array}$ & $\begin{array}{l}\text { Keberhasilan guru dalam melakukan } \\
\text { pembelajaran daring pada situasi } \\
\text { pandemi Covid-19 ini adalah } \\
\text { kemampuan guru dalam berinovasi } \\
\text { merancang, dan meramu materi, } \\
\text { metode pembelajaran, dan aplikasi } \\
\text { apa yang sesuai dengan materi dan } \\
\text { métode dan tergantung pada } \\
\text { kedisiplinan semua pihak. }\end{array}$ & $\begin{array}{l}\text { Pembelajaran Daring } \\
\text { di masa Pandemi } \\
\text { akan lebih efektif dan } \\
\text { efisien bila guru } \\
\text { kreatif dalam meramu } \\
\text { dan menyajikan } \\
\text { materi serta menjalin } \\
\text { kerjasama dengan } \\
\text { berbagai pihak, } \\
\text { khususnya orang tua } \\
\text { peserta didik. }\end{array}$ \\
\hline 3 & $\begin{array}{lr}\text { Pemanfaatan } \\
\text { Teknologi } \\
\text { Pembelajaran di Media } \\
\text { Pandemi } & \text { Covid-19 } \\
\text { (Unik } & \text { Hanifah } \\
\text { Salsabila, } & \end{array}$ & $\begin{array}{l}\text { Dengan adanya e-learning tentu } \\
\text { pembelajaran menjadi lebih efektif } \\
\text { dan fleksibel bisa di akses dimana } \\
\text { saja dan kapan saja asalkan ada paket } \\
\text { internet yang mampu menjadi } \\
\text { penunjang. }\end{array}$ & $\begin{array}{l}\text { Pemanfaat Media E- } \\
\text { Learning dalam } \\
\text { pembelajaran sangat } \\
\text { efektif dan fleksibel } \\
\text { serta penunjang } \\
\text { keberhasilan } \\
\text { pencapaian tujuan } \\
\text { selama kuota tersedia } \\
\text { dan jaringan internet } \\
\text { stabil. }\end{array}$ \\
\hline 4 & $\begin{array}{l}\text { Pemanfaatan } \\
\text { Teknologi Informasi } \\
\text { dalam Pembelajaran } \\
\text { Tingkat Sekolah Dasar } \\
\text { pada Masa Pandemi }\end{array}$ & $\begin{array}{l}\text { Pembelajaran secara daring dapat } \\
\text { dilakukan dengan memanfaatkan E- } \\
\text { learning. E-learning adalah teknologi } \\
\text { informasi dan komunikasi untuk }\end{array}$ & $\begin{array}{l}\text { Pemanfaatan } \\
\text { Learning } \\
\text { pembelajaran dapat } \\
\text { membangkitkan } \\
\text { motivasi belajar }\end{array}$ \\
\hline
\end{tabular}




\begin{tabular}{|l|l|l|l|}
\hline $\begin{array}{l}\text { Covid-19 (Ni Komang } \\
\text { Suni Astini, 2020) }\end{array}$ & $\begin{array}{l}\text { mengaktifkan siswa untuk belajar } \\
\text { kapanpun dan dimanapun }\end{array}$ & $\begin{array}{l}\text { siswa karena bisa } \\
\text { belajar dan peroleh } \\
\text { bahan belajar kapan } \\
\text { dan di manapun }\end{array}$ \\
\hline
\end{tabular}

Hasil di lapangan sebelum dan sesudah menggunakan media E-Learning dalam pembelajaran pada mata Pelajaran Pendidikan Agama Kristen dapat dilihat pada tabel 2 berikut ini:

Tabel 2. Hasil Pembalajaran Pendidikan Agama Kristen

\begin{tabular}{|c|c|c|c|c|c|}
\hline \multirow{2}{*}{$\begin{array}{l}\text { Sebelum } \\
\text { Menggunakan } \\
\text { Learning }\end{array}$} & \multicolumn{2}{|c|}{ Hasil } & \multirow{2}{*}{$\begin{array}{c}\text { Setelah } \\
\text { Menggunakan } \\
\text { E-Learning }\end{array}$} & \multicolumn{2}{|c|}{ Hasil } \\
\hline & Jumlah & Persentase & & Jumlah & Persentase \\
\hline Keaktivan Siswa & 18 orang & $40 \%$ & Keaktivan Siswa & $\begin{array}{l}40 \\
\text { orang }\end{array}$ & $90 \%$ \\
\hline Pengumpulan Tugas & 15 orang & $35 \%$ & $\begin{array}{l}\text { Pengumpulan } \\
\text { Tugas }\end{array}$ & $\begin{array}{l}36 \\
\text { orang }\end{array}$ & $80 \%$ \\
\hline $\begin{array}{l}\text { Jumlah Obyek } \\
\text { Penelitian }\end{array}$ & 45 orang & & & $\begin{array}{l}45 \\
\text { orang }\end{array}$ & \\
\hline
\end{tabular}

Di tengah pembatasan kegiatan, menghindari kerumunan pertemuan guru dengan peserta didik akibat Pandemi Covid 19, sangat memungkinkan pemanfaatan media e-learning (pembelajaran secara elektronik) secara efektif dan efisien. E-learning telah menyederhanakan proses pembelajaran yang dilakukan melalui jarak jauh menggunakan media elektronik dengan interaksi tatap muka secara virtual.

Pemanfaatan Media E-Learning dalam proses pembelajaran Pendidikan Agama Kristen bagi 45 siswa kelas X SMA Negeri 2 Tanjung Selor tetap terlaksana di tengah Pandemi Covid 19, di mana tatap muka belum diijinkan, namun melalui pembelajaran dengan memanfaatkan media E-Learning guru dan siswa tidak dihalangi oleh ruang, waktu dan tempat. Pertemuan secara virtual memanfaatkan media e-learning dalam rangka pembelajaran Pendidikan Agama Kristen dapat dilaksanakan kapan saja, dari rumah masing-masing tanpa membuang waktu ke sekolah, tanpa harus mengeluarkan biaya transportasi lagi.

Efisiensi pemanfaatan media E-Learning dalam pembelajaran didukung oleh beberapa faktor, yaitu:

1. 95 Persen siswa memiliki Hand Pone Android yang mempermudah mengakses internet, masuk dalam Link E-Learning.

2. Semua siswa memperoleh bantuan pembelian kuota internet dari Bantuan Operasional Sekolah.

3. Siswa berdomisili di área / daerah yang terjangkau jaringan internet.

4. Sekolah memfasilitasi link E-Learning bagi semua guru.

Indikator Efisiensi pemanfaatan media E-Learning dalam pembelajaran Pendidikan Agama Kristen di SMA Negeri 2 Tanjung Selor sesuai dengan jenis atau métode penelitian kualitatif (persentase) dengan pendekatan deskriptip yaitu keaktivan siswa mengikuti pembelajaran, baik materi maupun kegiatan ibadah dan pengumpulan tugas yang diberikan guru. Dengan Deskripsi sebagai berikut: Jika keaktivan siswa mengikuti kegiatan pembelajaran dan pengumpulan tugas di bawah 60 persen dari jumlah siswa sebagai obyek penelitian, maka pemanfaatan media E-Learning dinyatakan tidak efisien. Sebaliknya jika keaktivan siswa dan pengumpulan tugas di atas 60 persen, maka pemanfaatan media E-Learning dalam pembelajaran dinyatakan efisien.

Rata-rata 90 persen (40 orang) dari 45 siswa yang aktif hadir dalam setiap pembelajaran Pendidikan Agama Kristen menggunakan media E-Learning. Hanya 5 persen ( 5 orang) yang 
kurang aktif. Kurang aktifnya 5 siswa tersebut karena berbagai faktor; rumah tempat tinggal belum terjangkau jaringan internet secara maksimal, fasilitas pendukung kurang memadai.

\section{B. PEMBAHASAN}

\section{Pembahasan Efisiensi Pemanfaatan E-Learning Dalam Pembelajaran Jarak Jauh}

E-learning merupakan pembelajaran fleksibel yang dilakukan melalui media elektronik tanpa terpaut dalam dimensi ruang dan waktu (Nugraheni \& Dina, 2017: 112). Pendapat serupa oleh Murtaningrum dan kawan, bahwa e-learning adalah hasil yang didapatkan dari kemajuan teknologi dengan memanfaatkan internet yang mudah untuk diterapkan sebagai alternatif media pembelajaran (Murtiningrum et al., 2013: 290).

E-learning sebagai proses pembelajaran alternatif juga mengajarkan kemandirian bagi peserta didik sebab ilmu pengetahuan yang didapatkan memiliki jangkuan luas dari berbagai sumber yang ada sehingga hasil belajar dapat mudah tercapai dengan baik (Mulyani, 2013: 1). Pembelajaran jarak jauh dengan e-learning dijadikan sebagai salah satu alternatif yang memberikan solusi pada keterbatasan interaksi tatap muka antara pendidik dan peserta didik (Gata, 2016: 33). Karena situasi dan kondisi Pandemi Covid 19 yang terjadi, memaksa guru dan murid untuk tidak ada tatap muka langsung dalam pelaksanaan pembelajaran.

Pembelajaran Pendidikan Agama Kristen di tengah Pandemi Covid mengalami masalah, banyak siswa yang tidak ikut pembelajaran walaupun telah menggunakan media zoom meeting, WhattsApp. Setelah mencari solusi mengatasi hal tersebut, maka dipakailah media E-Learning dengan aplikasi Videoscribe, di mana siswa dapat mengaksesnya kapan dan di manapun. Sangat efisien dan efektiv dari segi waktu dan biaya, karena media E-Learning difasilitasi oleh sekolah.

Hal tersebut sangat sesuai dengan teori atau pemaparan yang dijelaskan oleh Sutrisno dan Agung, bahwa Salah satu Media Pembelajaran yang dapat digunakan dalam Elektronik Learning adalah: Videoscribe, E-Learning Videoscribe dimana konsepnya ini dapat diakses dimana saja dan kapan saja dengan pengunaan data admin, guru dan siswa. Guru dapat membuat materi dengan videosribe yang diunggah pada e-learning lalu siswa bergabung pada kelas daring yang dibuat oleh guru atau admin, dalam kelas daring tersebut siswa dapat bertanya kepada guru menggunakan fitur chat yang tersedia (Sutrisno \& Agung, 2016).

Mubarok dan kawan-kawan memberi penguatan terhadap pemanfaatan media ELearning dalam pembelajaran jarak jauh bahwa Media E-learning adalah media yang cocok digunakan dalam menunjang proses pembelajaran jarak jauh karena dalam konsepnya media elearning memanfaatkan teknologi elektronik baik informasi ataupun komunikasi secara online (Mubarok et al., 2018).

Dikatakan pemanfaatan media E-Learning cukup efisien dalam pembelajaran Pendidikan Agama Kristen di SMA Negeri 2 Tanjung Selor karena keaktivan siswa mengikuti pembelajaran Pendidikan Agama Kristen sebelum menggunakan E-Learning sangat rendah. Yang aktif mengikuti hanya 40 persen (18 orang) dari 45 siswa kelas $\mathrm{X}$ yang menjadi obyek penelitian, dan yang aktif mengumpulkan tugas yang diberikan oleh guru hanya 35 persen (15 orang).

Setelah memanfaatkan / menggunakan media E-Learning yang difasilitasi sekolah, maka terjadi perubahan yang signifikan, yaitu; Siswa yang aktif mengikuti pembelajaran mencapai 90 persen atau 40 orang, dan yang aktif mengumpulkan tugas ada 80 persen, atau 36 orang. Solusi atau saran untuk 10 persen ( 5 orang) yang kurang aktif karena faktor jaringan internet kurang maksimal di rumah tempat tinggalnya, dan fasilitas komputer, Laptop atau HP yang dimiliki kurang memadai, dapat bergabung dengan temannya memiliki fasilitas memadai dan jaringan internet yang maksimal

Mark J. Rossenberg yang dikutip oleh Priambodo menjelaskan bahwa e-learning merupakan teknik pembelajaran yang dilakukan dengan menggunakan teknologi internet untuk menambah wawasan serta keterampilan dalam diri individu (Priambodo, 2013:3). Peserta didik dapat menambah wawasan melalui elearning karena akses yang dapat dilakukan kapanpun, 
sehingga mempermudah dalam menemukan jawaban-jawaban atas pertanyaan yang sering bermunculan.

Media E-learning adalah media yang cocok digunakan dalam menunjang proses pembelajaran jarak jauh karena dalam konsepnya media e-learning memanfaatkan teknologi elektronik baik informasi ataupun komunikasi secara online (Mubarok et al., 2018). Media elearning juga merupakan alat bantu dengan sistem penyajian materi pembelajaran melalui elektronik sepertiinternet, TV interaktif, computer based learning, maupun satelit (Permatasari \& Hardiyan, 2018).

Pembelajaran daring (E-Learning) sangat membantu siswa secara efisien dari sisi waktu yang terbatas dalam meningkatkan motivasi belajar siswa dimana pembelajaran yang dilakukan melalui aplikasi Videoscribe pada mata pelajaran Pendidikan Agama Kristen kelas XI di SMA Negeri 2 Tanjung Selor meningkatkan keaktifan mengikuti pembelajaran. Dengan media e-learning ini tidak dapat dibatasi oleh waktu dan ruang, dimana dan kapan saja siswa dapat belajar (Lee \&Lee, 2015).

Terdapat peluang besar pada era perkembangan teknologi komunikasi dan informasi bagi tatanan kehidupan untuk dimanfaatkan di tengah Pandemi Covid 19, salah satunya yaitu pada bidang pendidikan. Tradisi pembelajaran tatap muka secara langsung atau pembelajaran konvensional dialihkan menjadi pembelajaran digital dengan teknologi informasi yang disebut e-learning. Pembaharuan-pembaharuan yang ada di bidang pendidikan memberikan inovasi baru yang menyesuaikan dengan perkembangan teknologi, sehingga nuansa pembelajaran mampu menggugah gairah dalam belajar (Herlinah, 2014).

\section{Karakteristik E-Learning}

Nursalam menjelaskan bahwa E-learning memiliki Karakteristik yaitu (Nursalam, 2008:135) adalah:

a. Memanfaatkan jasa teknologi elektronik.

b. Memanfaatkan keunggulan komputer (digital media dan komputer networks)

c. Menggunakan bahan ajar yang bersifat mandiri (self learning materials) kemudian disimpan di komputer, sehingga dapat diakses oleh doesen dan mahasiswa kapan saja dan dimana saja.

d. Memanfaatkan jadwal pembelajaran, kurikulum, hasil kemajuan belajar, dan halhal yang berkaitan dengan administrasi pendidikan dapat dilihat setiap saat di komputer.

\section{Manfaat E-Learning.}

Selanjutnya Nursalam (2008:136) menjelaskan manfaat E-Learning adalah:

a. Fleksibel. E-learning memberi fleksibilitas dalam memilih waktu dan tempat untuk mengakses perjalanan.

b. Belajar Mandiri. E-learning memberi kesempatan bagi pembelajar secara mandiri memegang kendali atas keberhasilan belajar.

c. Efisiensi Biaya. E-learning memberi efisiensi biaya bagi administrasi penyelenggara, efisiensi penyediaan sarana dan fasilitas fisik untuk belajar dan efisiensi biaya bagi pembelajar adalah biaya transportasi dan akomodasi.

Pranoto, dkk (2009:309) menjelaskan bahwa manfaat E-Learning adalah:

a. Penggunaan E-learning untuk menunjang pelaksanaan proses belajar dapat meningkatkan daya serap mahasiswa atas materi yang diajarkan.

b. Meningkatkan partisipasi aktif dari mahasiswa.

c. Meningkatkan partisipasi aktif dari mahasiswa.

d. Meningkatkan kemampuan belajar mandiri mahasiswa.

e. Meningkatkan kualitas materi pendidik dan pelatihan.

f. Meningkatkan kemampuan menampilkan informasi dengan perangkat teknologi informasi, dimana dengan perangkat biasa sulit dilakukan. 


\section{Kelebihan E-Learning}

Kelebihan E-learning ialah memberikan fleksibilitas, interaktivitas, kecepatan, visualisasi melalui berbagai kelebihan dari masing-masing media (Sujana, 2005 : 253).

L. Tjokro $(2009,187)$ menyebutkan 4 kelebihan E-Learning, yaitu:

a. Lebih mudah diserap, artinya menggunakan fasilitas multimedia berupa gambar, teks, animasi, suara, video.

b. Jauh lebih efektif dalam biaya, artinya tidak perlu instruktur, tidak perlu minimum audiensi, bisa dimana saja, bisa kapan saja, murah untuk diperbanyak.

c. Jauh lebih ringkas, artinya tidak banyak formalitas kelas, langsung pada pokok bahasan, mata pelajaran sesuai kebutuhan.

d. Tersedia $24 \mathrm{jam} / \mathrm{hari}-7 \mathrm{hari} /$ minggu, artinya penguaasaan materi tergantung pada semangat dan daya serap siswa, bisa dimonitor, bisa diuji dengan e-test.

Pembelajaran daring (E-Learning) sangat membantu siswa secara efisien dari sisi waktu yang terbatas dalam meningkatkan motivasi belajar siswa dimana pembelajaran yang dilakukan melalui aplikasi Videoscribe pada mata pelajaran Pendidikan Agama Kristen kelas XI di SMA Negeri 2 Tanjung Selor meningkatkan keaktifan mengikuti pembelajaran.

Permasalahan yang terjadi di lapangan, kurang aktivnya siswa dalam mengikuti pembelajaran Pendidikan Agama Kristen yang disebabkan oleh mewabahnya Covid 19 Pendidikan yang melarang pembelajaran tatap muka sudah terjawab atau terselesaikan melalui pemnafaat media E-Learning.

Walaupun E-Learning memiliki kekurangan seperti: membutuhkan peralatan tambahan, kurangnya interaksi antara guru dengan murid, dan interaksi social antara murid, namun dalam mengatasi terhentinya pelaksanaan pembelajaran tatap muka karena Pandemi Covid 19, maka pemanfaatan media E-Learning dalam proses pembelajaran menjadi solusi yang tepat .

Dalam situasi Pandemi Covid 19 yang mewabah, menghentikan seluruh program Pendidikan, kemajuan teknologi informasi dan komunikasi hadir memberikan solusi agar program Pendidikan tetap berjalan walaupun tanpa tatap muka secara langsung. Dengan memanfaatkan E-Learning, maka program pembelajaran dapat dilaksanakan dengan efisien di tengah waktu yang terbatas.

\section{KESIMPULAN}

Pelajaran Elektronik (E-Learning) merupakan media, sarana yang sangat menunjang pelaksanaan pembelajaran Pendidikan Agama Kristen pada SMA Negeri 2 Tanjung Selor secara efisien. Meningkatkan motivasi dan keaktivan siswa Kristiani Kelas X SMA Negeri 2 Tanjung Selor berjumlah 45 orang dalam mengikuti pembelajaran Pendidikan Agama Kristen tanpa dibatasi oleh ruang, dan waktu.

Tujuan penelitian tercapai yaitu terkait alasan perlunya media E-Learning dimanfaatkan dalam pembelajaran di masa Pandemi Covid 19. Telah terjawab dari penjelasan Mubarok dan kawan-kawan memberi penguatan terhadap pemanfaatan media E-Learning dalam pembelajaran jarak jauh bahwa Media E-learning adalah media yang cocok (tepat) digunakan dalam menunjang proses pembelajaran jarak jauh karena dalam konsepnya media e-learning memanfaatkan teknologi elektronik baik informasi ataupun komunikasi secara online.

Kemudian tujuan ke 2 (dari rumusan masalah kedua) terkait Efisiensi sudah teridentifikasi yaitu memberi efisiensi biaya bagi administrasi penyelenggara, efisiensi penyediaan sarana dan fasilitas fisik untuk belajar dan efisiensi biaya bagi siswa dalam hal transportasi. Jauh lebih efektif dalam biaya, artinya tidak perlu instruktur, tidak perlu minimum audiensi, bisa dimana saja, bisa kapan saja, murah untuk diperbanyak; Jauh lebih ringkas, artinya tidak banyak formalitas kelas, langsung pada pokok bahasan, mata pelajaran sesuai kebutuhan. 


\section{DAFTAR PUSTAKA}

A. Mubarok, Arthur, R., \& Handoyo, S. S. (2018). Pengembangan Pembelajaran E -Learning Mata Kuliah PTM/Jalan Raya Pendidikan Vokasional Konstruksi Bangunan Fakultas Teknik Universitas Negeri Jakarta. Jurnal PenSil, 7(2).

Astini, Ni Komang Suni. (2020). Pemanfaatan Informasi Dalam Pembelajaran Tingkat Dasar pada Masa Pandemi. Jurnal Lempuhyang Lembaga Penjamin Mutu STKIP Agama Hindu Amlapura.

Ahmad, Yurianto, \& Bambang Wibowo, K. P. (2020). PEDOMAN PENCEGAHAN DAN PENGENDALIAN CORONAVIRUS DISEASE (COVID-19) (M. I. Listiana Azizah, Adistikah Aqmarina (ed.)

C.G. Priambodo. (2013). Pengaruh Penerapan E-Learning Terhadap Peningkatan Motivasi dan Efektivitas Belajar Menurut Keragaman Siswa Dan Orang Tua : 104 Studi Kasus SMALB Pangudi Luhur Jakarta. Faktor Exacta,

G. Gata. (2016). Penggunaan Technology Acceptance Model Dalam Kajian E-Learning Dari Sudut Pandang Pengguna (Studi Kasus Fakultas Teknologi Informasi Universitas Budi Luhur).

Harmani, Sri. (2020). Efektivitas Pembelajaran Daring Di masa Pandemi Covid 19. Jakrata : BDK Kementerian Agama RI.

Herlinah. (2014). Pengaruh Penggunaan Multimedia Interaktif Terhadap Minat Belajar Mahasiswa Pada Stmik Handayani Makassar.

I. Permatasari, \& Hardiyan, H. (2018). Pengaruh E-Learning Sebagai Media Pelatihan dan Pengembangan Terhadap Kinerja Karyawan BCA KCU Tangerang. Jurnal Sistem Informasi Dan Komputer, 7(1).

Mahmud. (2011). Metode Penelitian Pendidikan, Bandung, CV Pustaka Setia.

M. Agustin. (2013). Pemanfaatan E-Learning Sebagai Media Pembelajaran.

Nursalam dan Ferry Efendy. (2008). Pendidikan Dalam Keperawatan. Jakarta. Salemba Medika.

Nopriati. (2020). Penggunaan E-Learning Madrasah di Tengah Pandemi Covid 19. www.stit.alkipayahriau.ac.id,

Nurhaida, \& Musa, M. I. (2015). Pelayanan Pendidikan Yang Berkualitas di Era Global Dalam Mengembangkan Potensi Peserta Didik Secara Maksimal. Jurnal Pesona Dasar.

Pranoto, dkk. (2008). Sain dan Teknologi. Jakarta : PT.Gramedia Pustaka Utama.

Salsabila, Unik Hanifah, dkk. (2020). Pemanfaatan Teknologi Media Pembelajaran di Masa Pandemi Covid-19. Jurnal Pendidikan Dasar Universitas Achmad Dahlan.

Sugiyono. (2012). Metode Penelitian Kuantitatif Kualitatif dan R\&D. Alfabeta.

T. Murtiningrum, Ashadi, A., \& Mulyani, S. (2013). Pembelajaran Kimia Dengan Problem Solving Menggunakan Media E-Learning Dan Komik Ditinjau Dari Kemampuan Berpikir Abstrak Dan Kreativitas Siswa. Jurnal Inkuiri.

W. Mulyani. (2013). Pengaruh Pembelajaran Berbasis E-Learning terhadap Hasil Belajar Siswa pada Konsep Impuls dan Momentum. Skripsi. Universitas Islam Negeri Syarif Hidayatullah Jakarta

Y.Lee, \& Lee, D. 2015. A Study on the Factors Influencing the Learning Satisfaction in E- learning based Occupational. Safety and Health Education for Migrant Workers in Korea. https://doi.org/10.1016/j.shaw.

Zed, Mestika. (2008). Metode Penelitian Kepustakaan,. Jakarta : Yayasan Obor Indonesia.

Menteri Pendidikan. (2020). Surat Edaran Nomor 3 Tahun 2020 Tentang Pelaksanaan Pendidikan dalam Masa Darurat CoronaVirus (COVID-19). Menteri Pendidikan..

T. Sutrisno, \& Agung, Y. A. 2016. Pengembangan Media Videoscribe Berbasis E-Learning Pada Mata Pelajaran Komunikasi Data Dan Interface Di SMKSunan Drajat Lamongan. Jurnal PendidikanTeknik Elektro, 05(03), 